\title{
Ecological engineering education: ways of formation and development
}

\author{
Larisa Komarova*, Vladimir Somin, and Yulia Lazutkina \\ Polzunov Altai State Technical University, 656038 Lenina Str., 46, Barnaul, Russia
}

\begin{abstract}
A system approach based on ecological and economic development required organizing the specialists training in the field of industrial ecology which was first established in our country in the 70s of the last century. In Polzunov Altai State Technical University (AltSTU) at the Department of Chemical Engineering and Engineering Ecology the training of environmental engineers began in the following areas: protection of the atmosphere, hydrosphere and lithosphere from industrial pollution with a specialization in wasted gases purification, wastewater treatment and solid waste recycling. Along with the educational process the scientific direction of creating energy efficient and resource-saving low-waste technologies and natural and waste water treatment was organized. In this area a large number of $\mathrm{PhD}$ and doctoral works based on innovative technologies in the field of separation of liquid industrial mixtures - wastes of various industries, as well as water treatment and water purification processes, were performed. More than 1000 environmental engineers have been trained since the creation of the program. Most of them stayed to work in Altai Krai. The accumulated experience made it possible to create a system of advanced training for engineering personnel in the field of environmental protection and ecological security and to win the Russian presidential grants including overseas internships in Sweden and Finland. This allowed to get acquainted with the concept of the best available technologies in the field of environmental protection for sustainable development.
\end{abstract}

\section{Introduction}

The industrial production development all over the world has raised the question of the increasing negative impact on the environment and the adoption of specific measures to reduce this impact. It required a revision of traditional principles of production, a systematic approach based on the greening of economic development. This in its turn required the training of specialists in industrial ecology. Therefore, in the 70s of the last century, in a number of leading universities of the country in the cities of Moscow, Kazan, St. Petersburg and also in Barnaul at Polzunov Altai State Technical University (AltSTU), the training of environmental engineers started. The newly created specialty was included in various directions. At present it is included in the integrated group of training areas 18.00.00

\footnotetext{
*Corresponding author: htie@mail.ru
} 
"Chemical technologies" in the direction (level) "Energy and resource-saving processes in chemical technology, petrochemistry and biotechnology" (bachelors and masters programs

\section{Main body}

The specialists are trained at the Department of Chemical Engineering and Engineering Ecology, the main scientific direction of which is the creation of energy and resource-saving technologies and the organization of closed water cycles. A large number of $\mathrm{PhD}$ and doctoral works in the field of separation of hardly separable liquid industrial mixtures, which are wastes of various industries, as well as innovative technologies of water treatment and water purification were performed in this area. The mentioned scientific base laid the foundation for the organization and further development of environmental engineers training program.

The scientific school "Development of Theoretical Foundations and Practical Implementation of Low-waste Resource-saving Technologies, Natural and Waste Water Treatment" was created at the department.

New modern laboratories were created, in the equipping of which the industrial enterprises of the city of Barnaul and Altai Krai greatly assisted. The educational and methodological literature was published. It was awarded a medal and diplomas of the USSR Exhibition of Economic Achievements.

The changing nature of industrial relations in Russia required training specialists for market economy in the field of environmental engineering as well. Along with the disciplines of natural science cycle and vocational subjects the curriculum includes the disciplines defining the profile of environmental engineering.

Among them there are principles of microbiology and biotechnology, environmental management and audit, environmental monitoring and control, energy and resource conservation management, environmental support of economic activity, waste management, as well as engineering methods of hydrosphere protection, atmospheric protection technology, principals of technological processes design [1 -7].

The department is fit up with modern equipment. It has a computer class. Laboratory facilities are connected to computer technology, lecture classrooms have multimedia equipment. There are postgraduate and doctoral courses in the specialty. Graduates successfully defend their dissertations and stay to work at the university. The best of them replace the older generation of teachers, maintaining the continuity of the scientific school and educational process. Since the creation of the specialty more than 1,000 environmental engineers and about 100 bachelors and masters have been trained. They work in environmental protection agencies of Altai Krai, at industrial enterprises, in design institutes, various companies and educational institutions.

The first state-budget problem laboratory "Technology of recycled industrial materials recuperation" was organized in the structure of the department, where since the opening of the specialty in environmental engineering the scientific base for training highly qualified personnel - candidates and then doctors of sciences was concentrated [8-12].

In 2012-2014 grants from the Russian Foundation for Basic Research and the Ministry of Education of the Russian Federation for holding scientific interregional and international conferences on environmental problems of nature management were won.

In order to improve the quality of education and training skills of scientific work on the basis of Polzunov Altai State Technical University and the Institute of Water and Environmental Problems of SB RAS a university and academic department of environmental problems in technology and energy was created. The organization of such a department became possible due to the presence of a specialty in environmental protection at the university and a research direction in ecology and land hydrology at the academic institute, where the dissertation council in this direction is available. The availability of analytical 
research center with modern equipment and highly qualified scientific staff allowed to fully use the scientific and educational potential of the university-academic department, which contributed to improving the quality of training in the field of environmental engineering and personnel of the highest qualification.

The experience of training engineering and academic and teaching staff available at the department since the 2000s made it possible, , to begin professional training of persons for the right to work with hazardous waste, and advanced training in the field of environmental safety of economic activities.

Polzunov Altai State Technical University is the only one in Altai Krai that three times became a winner of the competitive selection for the Presidential program of engineering personnel professional development for 2012-2014. In the structure of the Institute of Further Professional Education Development at Altai State Technical University on the basis of the Department of Chemical Engineering and Engineering Ecology there was developed an additional professional development program in the field of waste management. Within this program the training of engineering staff of industrial enterprises, design organizations, public authorities were carried out. The program made it possible to carry out internships in Sweden and Finland. The trainees visited a waste recycling company, a heating plant that burns garbage and biofuel, a plant that produces biogas from sewage sludge, a heating plant that uses treated wastewater, a firm that produces high-tech waste recycling equipment. The trainees got acquainted with the concept of using the best available technologies in the field of environmental protection, the essence of which is to combine several sectors of urban economy into one integrated system, in particular, water supply and wastewater treatment, energy, public transport and waste management. All advances in environmental construction are used; all waste generated in the area is sorted into different types, which are sent by vacuum through an underground collector for recycling. From the combustible part of the waste heat is obtained, which goes to the heating system of the buildings.

The studied foreign experience was used in the project activities, municipal management and the educational process in Polzunov Altai State Technical University.

Teachers and employees of Chemical Engineering and Engineering Ecology Department at Altai State Technical University actively participate in the work of nature protection bodies, being members of the Public Council of Altai Krai Ministry of Natural Resources and Administration of Federal Service for Supervision of Natural Resources in Altai Krai and the Republic of Altai, the personnel commission of General Department of Natural Resources and Environment of Altai Krai, the Council on science, knowledge-intensive technologies and innovative development at Altai Krai Legislative Assembly.

\section{Results and Discussion}

Over 50 years more than 1000 specialists in the field of ecological engineering for the enterprises of Altai Krai and neighboring regions have been prepared. Highly qualified personnel have been trained. They are candidates and doctors of science who carry out the educational process in universities, conduct scientific research and implement their results in production. Professional development of engineering staff of industrial enterprises, design organizations, public authorities in the field of environmental safety of economic activity is carried out. This made a significant contribution to solving environmental problems of Altai Krai and to the formation of mechanisms for sustainable development of West Siberian region. 


\section{Conclusions}

Training of environmental engineers for industrial enterprises, business entities, and government agencies plays an important role in the development of our country.

\section{References}

1. O.M. Gorelova, Industrial Ecology, 186 (2014)

2. O.Yu. Sartakova, Fundamentals of microbiology and biotechnology, 256 (2015)

3. L.A. Kormina, L.N. Beldeeva, L.F. Komarova, Environmental Management and Audit., 125 (2014)

4. V.A. Somin, L.F. Komarova, Y.S. Lazutkina, Environmental Impact Assessment and Environmental Expertise, 127 (2011)

5. Yu.S. Lazutkina, L.N. Beldeeva, V.A. Somin, Hazardous waste management, 130 (2015)

6. L.F. Komarova, V.A. Somin, Engineering methods of hydrosphere protection, 281 (2020)

7. L.A. Kormina, Yu.S. Lazutkina, Technology of gas emissions purification, 263 (2020)

8. V.A. Somin, V.I. Zanosova, L.F. Komarova, Water Resources, 43(1), 121 (2016)

9. O.M. Gorelova, L.F. Komarova, Chemistry and Technology of Fuels and Oils, 52(1), 38 (2016)

10. I.A. Lebedev, E.V. Kondratyuk, L.F. Komarova, Russian Journal of Applied Chemistry, 83(10), 1877 (2010)

11. I.A. Bakhtina, M.S. Khristenko, N.G. Andreeva, L.F. Komarova, Russian Journal of Applied Chemistry, 79(11), 1775 (2006)

12. P.A. Krivosheev, L.F. Komarova, M.A. Poletaeva, I.A. Lebedev, S.S. Lavrinenko, Russian Journal of Applied Chemistry, 77(9), 1515 (2004) 